\title{
WALKER CIRCULATION AND GLOBAL WARMING LESSONS FROM THE GEOLOGIC PAST
}

BY ANA CHRISTINA RAVELO

Short-lived El Niño events are temporary changes in tropical Pacific conditions that are responsible for dramatic perturbations to "normal" tropical climate, such as drought in Indonesia and flooding on the Peruvian coast, and to global climate, such as warmer-thanaverage wintertime temperature in parts of North America and drier-than-average climate in Australia. A tremendous amount is known about the dynamics and driving forces of the El Niño phenomenon (Cane, 2005; Philander and Fedorov, 2003a), which is useful for the prediction of short-term interannual climate variability. Although modern El Niño events demonstrate the potential impact that the tropics have on global climate on any timescale, there is recognition that El Niño dynamics do not dictate long-term changes in tropical Pacific climate (Boccaletti et al., 2004; Fedorov and Philander, 2000; Liu and Yang, 2003) and that the factors determining

Ana Christina Ravelo (acr@es.ucsc.edu) is Professor, Ocean Sciences Department, University of California, Santa Cruz, CA, USA. long-term tropical conditions need to be constrained. As global warming occurs, is the mean state of the tropical Pacific likely to change, and will there be subsequent far-field effects like those that occur interannually due to El Niño events?

One way to approach this question is to investigate past tropical Pacific climate change in order to evaluate the stability/instability of tropical climate and the nature and mechanisms of past changes if they occurred. Because the length of the instrumental record of past climate change is limited to a few centuries, paleoclimate records (from geological archives such as sedimentary sections, ancient plankton, and corals) are needed to evaluate past tropical climate changes. In a major effort, particularly relevant to current and future climate change studies, the Ocean Drilling Program (ODP) recovered long sequences of undisturbed sediments that were deposited during past times of global warmth.

The last time that the Earth was significantly warmer than today for a sustained period of time was during the early Pliocene warm period, which lasted from about 5 to 3 million years ago (Ma). Atmospheric carbon dioxide concentrations were similar to or only slightly ( 30 percent) higher than preanthropogenic values (Van der Burgh et al., 1993; Kurschner et al., 1996; Raymo et al., 1996), while global temperature was about $2-3^{\circ} \mathrm{C}$ warmer than today (Dowsett et al., 1996; Sloan et al., 1996; Haywood and Valdes, 2004). Paradoxically, most climate models of future global warming over the next century predict that the sensitivity of global climate to a 30-percent increase in carbon dioxide would be significantly less than $2-3^{\circ} \mathrm{C}$ (Intergovernmental Panel on Climate Change, 2001). While it is possible that climate models underestimate the long-term warming that might occur as a response to carbon dioxide changes, it is also possible that carbon-dioxide concentrations were a relatively minor, perhaps even insignificant, factor in determining Pliocene warmth. Given that the Pliocene had relatively similar atmospheric carbon dioxide levels to today, it is an ideal time period in which to study other factors that can influence global 

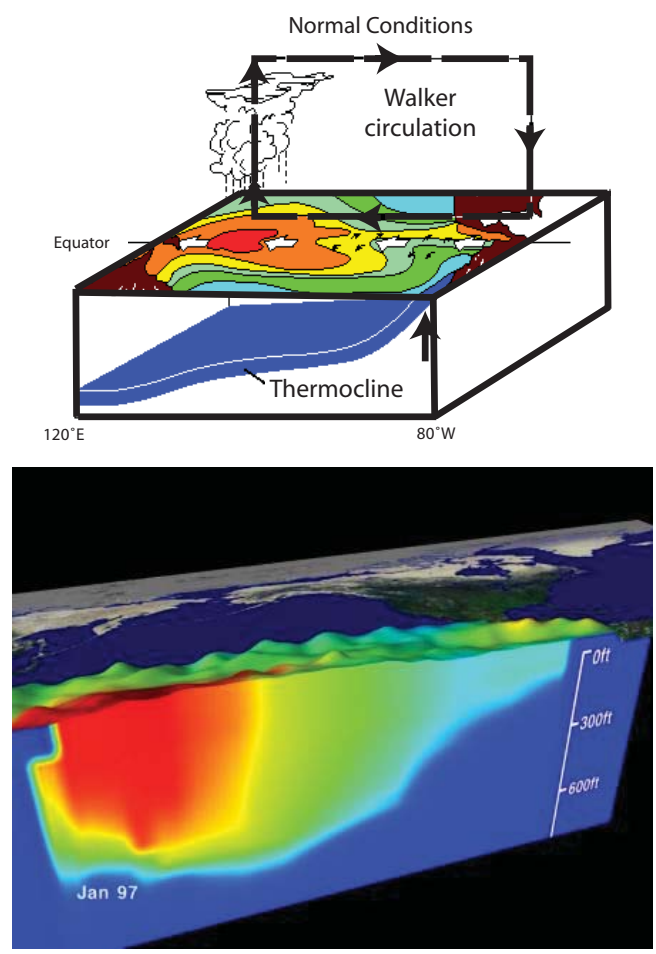

January 1997 Normal
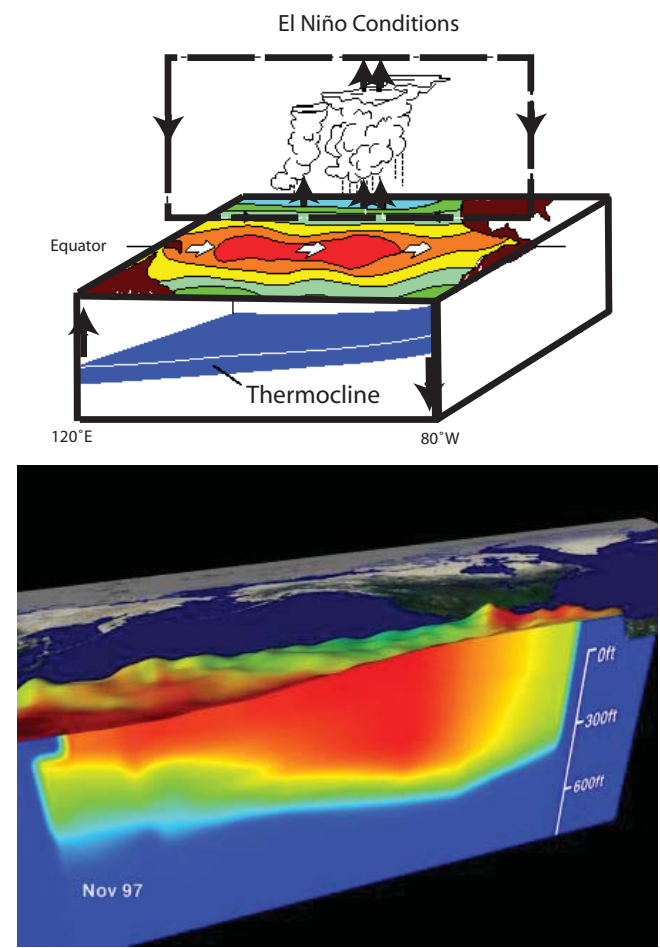

November 1997 El Niño
Figure 1. Comparison of normal and El Niño conditions in the modern ocean (adapted from NOAA's El Niño website, http://www.pmel. noaa.gov/tao/elnino). Schematic of normal conditions includes strong Walker circulation or convective loop, and strong east-west temperature gradient and thermocline tilt (upper left); schematic of El Niño conditions includes weakened Walker circulation, temperature gradient, and thermocline tilt (upper right). Equatorial Pacific cross sections of temperature prior to El Niño (January 1997) when sub-surface temperature gradient is relatively large (lower left), and during an El Niño (November 1997) when sub-surface temperature gradient is relatively small (lower right). Sea surface height is represented by bumps. Temperature range is from $30^{\circ} \mathrm{C}$ (red) to $8^{\circ} \mathrm{C}$ (blue). The thermocline is at approximately the $20^{\circ} \mathrm{C}$ isotherm (the border between dark blue and cyan). temperature-those that impact Earth's albedo (reflectivity of incoming solar radiation) and those that impact atmospheric water-vapor content (the planet's most important greenhouse gas). As such, studies of the tropics are particularly relevant because they are the main source of water vapor to the atmosphere and because tropical clouds, which are poorly represented in climate models, can have a large impact on albedo.

A major transition occurred from the warm climate of the early Pliocene to the cool, ice-age climate of the late Pliocene and Pleistocene, with gradual cooling starting at or before $3.5 \mathrm{Ma}$ and the development of the largest Northern Hemisphere ice sheets by about 1.0 Ma. The onset and evolution of the Northern Hemisphere ice ages represented a fun- damental change in climate conditions and provides the opportunity to test theories about how long-term climate changes occur. For example, interactions among ocean circulation, water-mass distribution, ocean stratification, and the size and distribution of ice sheets and sea ice can be investigated by monitoring changes in these components of the Earth's system as global climate evolved. These sorts of investigations, using deepsea sediment cores recovered by ODP, are responsible for the generation of some of best records of the early Pliocene warm period and the transition to the ice ages. This study is one example of such an investigation that "uses" the geological record of climate change to assess the stability of tropical Pacific and its influence on long-term global climate change.

\section{BACKGROUND}

Today, the "normal" mean state of the tropical Pacific is highly asymmetric: the west equatorial Pacific has a relatively warm sea surface temperature, low surface air pressure (rising air), and rainy wet conditions, while the eastern equatorial Pacific has a cold "tongue" of water, higher surface air pressure (sinking air), and dry conditions. The west-east surface air pressure gradient drives the surface trade winds from east to west; the rising air in the west returns, in winds that flow aloft, to the east where it sinks, producing an atmospheric circulation cell called Walker circulation (Figure 1). The surface trade winds cause upwelling - the vertical mixing of water from the sub-surface water into the surface photic zone. Wind-driven upwelling of 
cold water in the east amplifies the westeast temperature difference, which further augments the surface-air pressure gradient and the trade winds. These airsea interactions comprise a positive feedback loop that maintains strong easterly trade winds and Walker circulation and the highly asymmetric temperature (Figure 2) and precipitation patterns across the Pacific (Figure 1).

This west-to-east temperature asymmetry is intimately related to westto-east differences in the depth of the thermocline, the steep vertical thermal gradient that separates the warm surface mixed layer above from the cold water of the deep ocean below. The thermocline is located below $\sim 200 \mathrm{~m}$ in the western equatorial Pacific and slopes upward to shallow depths of around 30-50 $\mathrm{m}$ in the eastern equatorial Pacific. The easterly trade winds cause upwelling all along the equator; however, the resulting sea surface temperature is different in the west than in the east. In the west, where the thermocline is deep, the winds cause upwelling of warm, nutrient-poor water, while in the east where the thermocline is shallow, the winds cause cool, nutrient-rich water from within and below the thermocline to upwell, creating the observed cold tongue of surface water (Figures 1 and 2).

El Niño events are extreme swings, or interannual variability, superimposed on the stable mean zonally asymmetric state described above. During an El Niño event, which occurs every few years, Walker circulation temporarily weakens or breaks down, accompanied by more symmetrical west-east patterns of sea surface temperature, sea level pressure, and thermocline depth (Figure 1). The temporary depression of the thermocline in the east equatorial Pacific during an El Niño event is followed by a rise in the thermocline at the end of the event, which allows cold water to upwell and the east equatorial cold tongue to persist once again. The west-east temperature and pressure gradient, and strong Walker circulation is re-established as "normal" conditions return. Although thermocline depth in the east equatorial Pacific varies both seasonally and interannually, the mean depth of the thermocline is rela- tively shallow, allowing the cold tongue and therefore strong Walker circulation to dominate tropical Pacific climate today. As such, it is important to understand whether the depth of the thermocline and strong Walker circulation are dominant and stable characteristics of tropical climate in past times, and to formulate theories that can predict how they might change in the future.

\section{WALKER CIRCULATION IN THE PLIOCENE}

Records of the oxygen-isotopic composition of benthic foraminiferal shells are primarily a reflection of change in global ice volume (see Box 1). A recently compiled stack of oxygen-isotope records from ODP sites around the globe serves as a good first-order representation of high-latitude ice-volume change for the last 5 million years (Lisiecki and Raymo, 2005) (Figure 3a). Although small ice sheets were present in the Northern Hemisphere in the Miocene and earliest Pliocene, during the early Pliocene warm period ( 3 to $5 \mathrm{Ma})$, those ice sheets were smaller than the

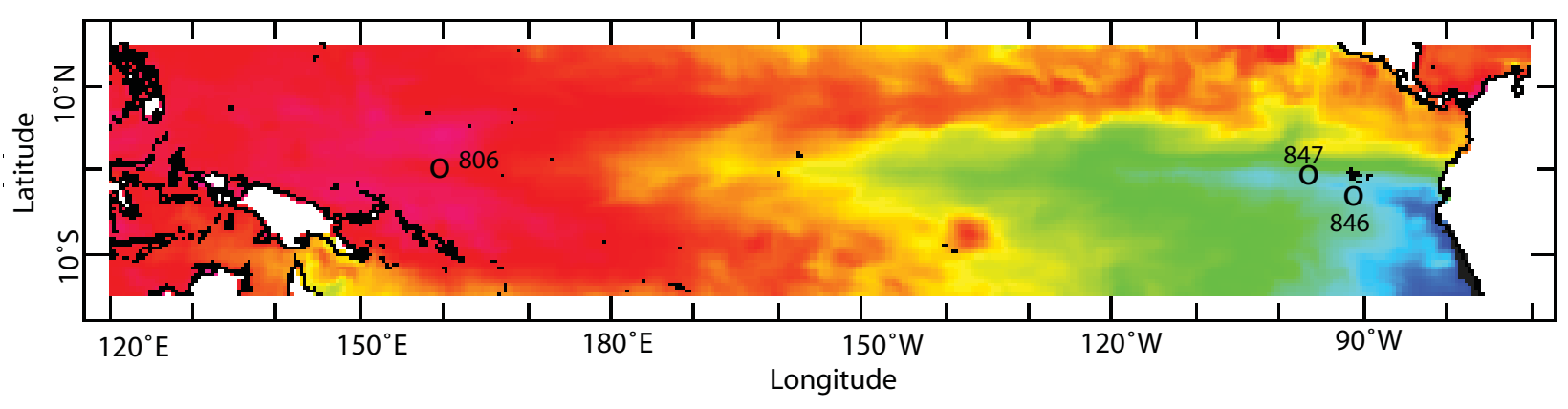

Figure 2. Sea surface temperature (SST) map of the world's tropical oceans (October climatology, CARTON-GIESE SODA v1.4.3 from IRI/LDEO data collection), identifying tropical sites used in this study: ODP Site $806\left(0^{\circ} \mathrm{N}, 159^{\circ} \mathrm{E}, 2,520 \mathrm{~m}\right.$ water depth), ODP Site 847 $\left(0^{\circ} \mathrm{N}, 95^{\circ} \mathrm{W}, 3,373 \mathrm{~m}\right.$ water depth), and ODP Site $846\left(3^{\circ} \mathrm{S}, 91^{\circ} \mathrm{W}, 3,296 \mathrm{~m}\right.$ water depth). 


\section{BOX 1. PALEOCEANOGRAPHIC PROXIES}

\section{Foraminifera Geochemistry}

Foraminifera are unicellular microorganisms that secrete calcium carbonate $\left(\mathrm{CaCO}_{3}\right)$ shells. Geochemical measurements of their fossil shells preserved in sediments accumulating in the deep sea can be used to reconstruct past oceanic conditions in which the foraminifera lived; benthic species are used to monitor conditions at the sediment-water interface and planktonic species are used to monitor conditions in the upper few hundred meters of the water column. Geochemical analyses of shells from drilled sediment sequences are used to generate long proxy records of climatic and oceanic change.

One of the most common tracers of climate change is oxygen isotope measurements $\left(\delta^{18} \mathrm{O}\right)$ of foraminiferal shells. Because $\mathrm{H}_{2}{ }^{16} \mathrm{O}$ evaporates more readily than $\mathrm{H}_{2}{ }^{18} \mathrm{O}$, the $\delta^{18} \mathrm{O}$ value of water vapor, cloud droplets, precipitation, and continental ice are low compared to that of seawater. When ice sheets grow, they act as reservoirs of huge amounts of water with relatively low $\delta^{18} \mathrm{O}$ values. Consequently, the $\delta^{18} \mathrm{O}$ of the ocean is relatively high when continental ice volume is high. Variations in the $\delta^{18} \mathrm{O}$ of the ocean, and therefore ice volume, can be monitored by measuring variations in the $\delta^{18} \mathrm{O}$ of foraminifera shells in the past. The $\delta^{18} \mathrm{O}$ of seawater can also vary as a function of hydrological processes (evaporation minus precipitation) and there is a temperature-dependent offset between the $\delta^{18} \mathrm{O}$ of $\mathrm{CaCO}_{3}$ shells and of seawater. Thus, foraminiferal $\delta^{18} \mathrm{O}$ records reflect a combination of ice-volume changes, local changes in evaporation and precipitation, and local changes in temperature (e.g., Rohling and Cooke, 1999; Ravelo and Hillaire-Marcel, in press). Nevertheless, a $\delta^{18} \mathrm{O}$ record derived from benthic foraminifera from the deep ocean, where these local effects are thought to be secondary, is considered to be a good first-order record of ice volume changes in past times (Figure 1).

At present, the most reliable method for reconstructing calcification temperature of foraminifera is the analysis of the magnesium-tocalcium ratios $(\mathrm{Mg} / \mathrm{Ca})$ of fossil $\mathrm{CaCO}_{3}$ shells. The incorporation of $\mathrm{Mg}$ relative to $\mathrm{Ca}$ into foraminiferal shells varies exponentially with calcification temperature (Nurnberg et al., 1996; Dekens et al., 2002; Anand et al., 2003). Although there can be post-depositional effects (e.g., dissolution), careful application of this technique has resulted in robust records of paleotemperature variations. $\mathrm{Mg} / \mathrm{Ca}$ analyses of surface dwelling planktonic foraminifera were made to generate several of the sea surface temperature records in Figure 3d.
Scanning Electron Microscope (SEM) image of Globigerinoides ruber from the Arabian Sea

(http://www.geo.vu.nl/ peef). The shell is approximately $300 \mu \mathrm{m}$ across. Frank Peeters kindly provided this image.

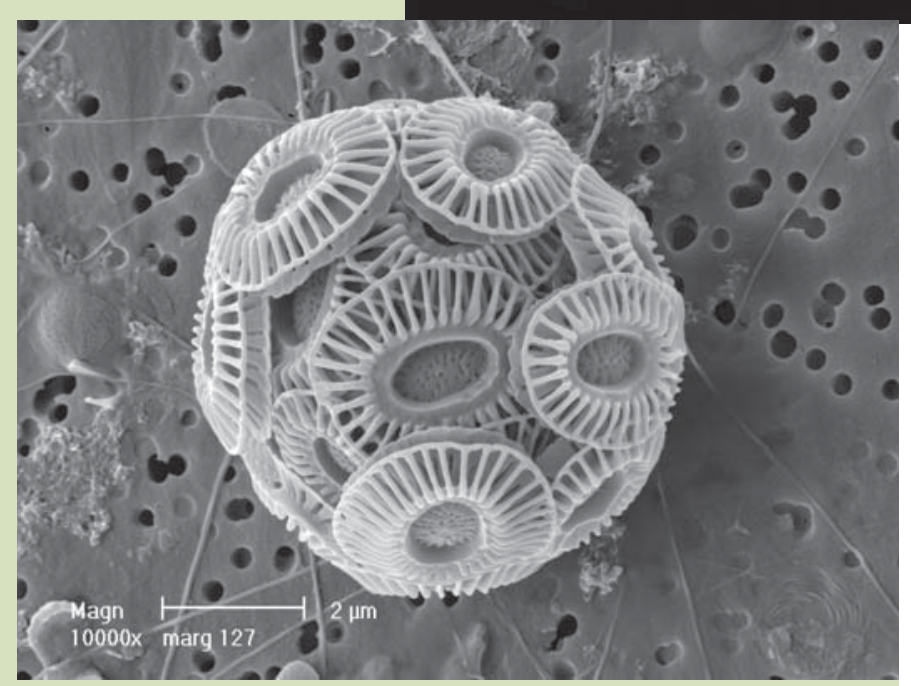

Scanning Electron Microscope (SEM) image of coccolithophore Emiliania huxleyi. Image was taken by Jeremy Young and printed with permission from the Natural History Museum, London. Go to http://www.noc.soton. ac.uk/soes/staff/tt/eh/ for more information on E. huxleyi.

\section{Alkenone Paleothermometry}

Within the fine fraction of deep-sea sediments are organic particles and compounds that were synthesized by marine algae. Just as foraminifera shells accumulate through time in layers of deep-sea sediment, so do these organic constituents. Within the organic fraction of the sediment are long-chain $\left(\mathrm{C}_{37}\right)$ ketones, synthesized by certain species of phytoplankton (coccolithophorid algae). Paleoceanographic studies analyze ketones, which occur with different saturation states, to calculate an alkenone unsaturation index $\left(U^{k^{\prime}}{ }_{37}\right)$. The $U^{k^{\prime}}$ index has a strong correlation with ocean temperatures in the modern ocean and has been extensively calibrated (Herbert, 2000). The $U^{k^{\prime}}{ }_{37}$ index provides an indicator of past temperature variations that is completely independent from the $\mathrm{Mg} / \mathrm{Ca}$ proxy, which is measured on calcite shells. Several of the sea surface temperature records shown in Figure $3 \mathrm{c}$ and $\mathrm{d}$ were generated by analyzing the $\mathrm{U}^{\mathrm{k}^{\prime}}{ }_{37}$ index in samples from downcore sediment sections. 


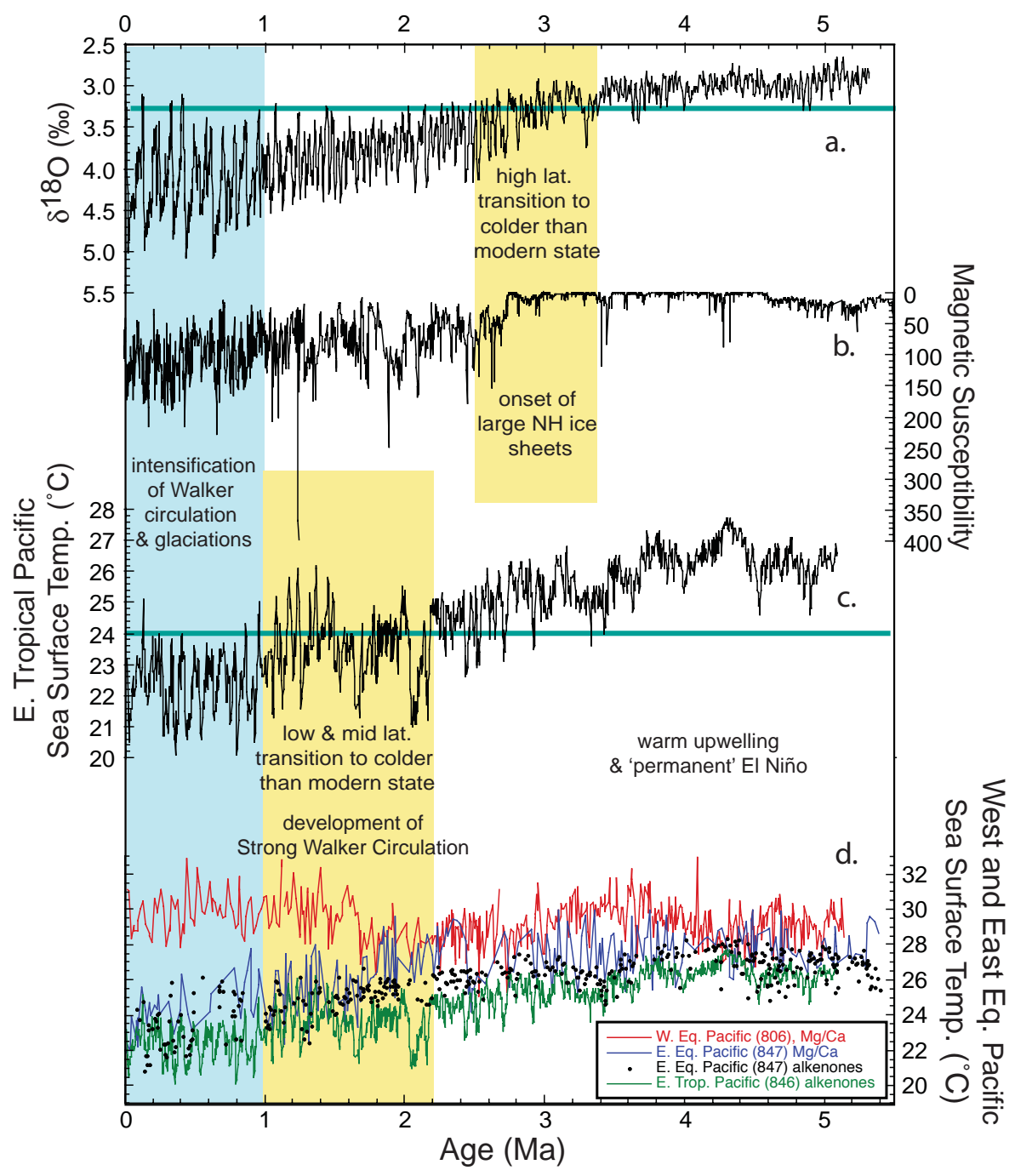

Figure 3. Records of regional climate and ocean change over the last 5 million years. (a) Stack of benthic oxygen isotope data (Lisiecki and Raymo, 2005) represents the growth of high-latitude ice sheets with the modern ice-volume size indicated by the green horizontal line. (b) The magnetic susceptibility record (Haug et al., 1999) indicates the concentration of ice-rafted debris in sediments in the North Pacific at ODP Site $882\left(50^{\circ} \mathrm{N}, 168^{\circ} \mathrm{E}, 3244 \mathrm{~m}\right.$ water depth). (c) The $U \mathrm{k}_{37}$-derived sea surface temperature record from Eastern Tropical Pacific ODP Site 846 (Lawrence et al., 2006) with the modern temperature indicated by the green horizontal line. (e) $\mathrm{The} \mathrm{Mg} / \mathrm{Ca}$ and $\mathrm{Uk}_{37}$ (alkenone) sea surface temperature records from the western tropical Pacific (ODP Site 806) compared to those from the eastern tropical Pacific (ODP Sites 847 and 846), showing the increase in west-east temperature difference across the equatorial Pacific as climate cooled. $\mathrm{Mg} / \mathrm{Ca}$ data is from Wara et al., (2005); $\mathrm{Uk}_{37}$ data from Site 847 are from Dekens et al. (in preparation). present-day Greenland ice sheet. ODP expeditions targeting high-latitude environments have shown that ice-rafted debris is rarely found in sediments of early Pliocene age in the Atlantic (Raymo et al., 1989) and Pacific (Haug et al., 1999) (Figure 3b), indicating that ice sheets were small, in agreement with the oxygen-isotope record of ice volume (Figure 3a). A map of early Pliocene sea surface temperature constructed using analyses of ODP material from around the world's oceans (Dowsett et al., 1996) indicates that temperatures in high-latitude regions were warmer than today by $\sim 4-8^{\circ} \mathrm{C}$ when ice sheets were small.

Studies using cores collected during ODP expeditions in upwelling regions (e.g., ODP Leg 138 in the East Equatorial Pacific, ODP Leg 167 along the California margin, ODP Leg 175 along the West African margin, ODP Leg 202 along the Peru-Chile margin) indicate that, in the warm early Pliocene, upwelling regions around the globe were relatively warm in the sub-tropics (Herbert and Schuffert, 1998; Marlow et al., 2000; Dekens et al., in preparation) and in the eastern equatorial Pacific (Wara et al., 2005; Lawrence et al., 2006) (Figures 2 and 3c, d). In contrast, at ODP Site 806 in the western equatorial Pacific (Figure 2), sea surface temperatures were similar to today (Figure 3d). Thus, the west-east temperature difference across the equatorial Pacific was reduced in the early Pliocene compared to today, much like it is during an El Niño event. The implication of a long-term reduction in sea surface temperature difference across the equatorial Pacific is that Walker circulation must have been weaker during the early Pliocene warm period; the mean state of 
the tropical Pacific resembled a permanent El Niño.

According to theoretical/modeling studies, the long-term mean state of tropical Pacific climate could be related to mean thermocline conditions (Liu and Huang, 2000; Philander and Fedorov, 2003b). Thermocline conditions would impact sea surface temperature in upwelling regions (e.g., a deeper thermocline would cause the east equatorial cold tongue region to be relatively warm), which in turn, due to air-sea feedbacks described above, would determine west-east gradients in climate and ocean parameters and the strength of Walker circulation. There is observational evidence from ODP Sites 847 and 851 in the eastern equatorial Pacific that the thermocline was indeed deeper and/ or warmer (Chaisson and Ravelo, 2000; Ravelo et al., 2006) during the early Pliocene. It is possible that the warmth of upwelling regions around the globe, the reduction in the tropical Pacific west-east temperature difference (Figure 3d), and Walker circulation were directly related to those thermocline conditions. Future work should be aimed at reconstructing thermocline conditions at multiple locations around the globe and should continue to use climate theory and models to elucidate the mechanisms that explain both the observed thermocline conditions and the paleotemperature patterns of the Pliocene warm period.

THE ROLE OF WALKER CIRCULATION IN GLOBAL

\section{CLIMATE CHANGE}

Because atmospheric carbon dioxide concentrations in the early Pliocene were only moderately higher than today, it is important to identify what caused global warmth during that period. The permanent El Niño-like state and reduced Walker circulation of the early Pliocene most likely had global impacts. A recent modeling study (Barreiro et al., 2005) investigated the impact of a reduced west-east temperature gradient and increased low-latitude temperatures on global climate; the study concluded that changes in low-latitude conditions had a strong effect. Specifically, the warmer temperatures of the eastern equatorial Pacific were accompanied by a reduction in low-level, highly reflective stratus clouds and by more evaporation and therefore more water vapor (a greenhouse gas). In this modeling study (Barreiro et al., 2005), lower albedo combined with higher greenhouse-gas content impacted global temperature by $0.5^{\circ}$ to $>2.0^{\circ} \mathrm{C}$, depending on the mean temperature and seasonality of the low-latitude oceans. Whereas, the impact of removing high-latitude ice had strong regional, rather than global, effects. Although much more work needs to be done, there is some evidence that early Pliocene warmth may be explained in part by tropical conditions, perhaps more so than the near-absence of Northern and/or Southern Hemisphere ice.

Perhaps the most significant impacts of permanent El Niño and reduced Walker circulation in the early Pliocene were through far-field regional climate responses to changes in the tropical Pacific (teleconnections). Continental climate during the early Pliocene was quite different than today, with anomalies, relative to modern, that are similar to the patterns of continental climate change that currently occur temporarily during short- lived El Niño events (Molnar and Cane, 2002). These anomalies include warmer summertime conditions in North America, drier climate in northeastern South America, and higher precipitation in Africa. In the climate simulations made by Barreiro et al. (2005), permanent El Niño conditions in low latitudes had their largest extratropical impacts on temperature of the North American continent. It may be that these El Niño-like teleconnections prevented the development of large ice sheets in the early Pliocene.

While the early Pliocene warm period gives us insight into the processes responsible for global warmth, regional expressions of the transition to the late Pliocene and Pleistocene ice ages can provide information about the mechanisms responsible for the cooling transition (Ravelo et al., 2004). As described above, low-latitude climate change can have a large impact on high-latitude climate, while high-latitude conditions can have a large impact on low-latitude atmospheric circulation (Chiang and Bitz, 2005; Haywood et al., 2005; Broccoli et al., 2006) and a large impact on ocean conditions that propagate to low latitudes ( Liu and Yang, 2003; Boccaletti et al., 2004; Fedorov et al., 2004). These complicated interactions result in high- and low-latitude climate change occurring synergistically, making it very difficult to tease apart cause from effect. However, by looking at the timing of climate changes in one region compared to another, it is possible to extract information about distinct climate processes. We assume that the growth of large Northern Hemisphere ice sheets had strong effects on atmospheric circulation regionally, and possibly even at subtropical and 
tropical latitudes. However, differences in the timing and nature of the development of strong Walker circulation relative to that of the ice sheets indicates that the tropical Pacific played a somewhat independent role in the Pliocene-Pleistocene climate transition.

The marked increase in global ice volume, or the onset of significant Northern Hemisphere glaciation, occurred gradually from 3.5 to $2.5 \mathrm{Ma}$ (Mudelsee and Raymo, 2005) (Figure 3a). Even though climate cooled gradually, some regions experienced more abrupt climate change, for example, rapid increases in ice-rafted-debris deposition (Raymo et al., 1989; Haug et al., 1999) (Figure 3b). Ice-age conditions were established by $2.5 \mathrm{Ma}$, with average Northern Hemisphere ice volume size surpassing and remaining larger than the present-day size of the Greenland ice sheet (Figure 3a). In contrast, records from ODP Sites 847 and 846 (Figure 2) indicate that cooling sea surface temperatures in the eastern equatorial Pacific (Figure $3 \mathrm{c}$, d) began earlier than 3.5 Ma and did not reach and remain cooler than today's values until $\sim 1.0 \mathrm{Ma}$. The west-east temperature gradient, and therefore Walker circulation, increased gradually, but the marked step at $\sim 1.6 \mathrm{Ma}$ (Figure 3d; sharp divergence of ODP Site 806 values in red away from ODP Site 847 values in blue) was not accompanied by an obvious increase in ice volume or ice-rafted debris (Figure $3 b)$. The "normal" conditions of the tropical Pacific were not established until the late Pleistocene (after 1.0 Ma); there were many times when the sea surface temperature in upwelling regions was warmer than today (Figure 3c, warmer values above green line) even while ice volume was greater than today between 2.5 and 1.0 Ma (Figure 3a, heavy values below green line).

While the tropical Pacific may respond to changes in high-latitude conditions such as land or sea-ice cover, which influence temperature gradients and winds (Raymo and Nisancioglu, 2003; Chiang and Bitz, 2005; Broccoli et al., 2006), there is building evidence that other processes must also play a role in tropical Pacific climate change during the Plio-Pleistocene transition. Evidence that the eastern equatorial thermocline was shoaling through the Pliocene, as discussed above, suggests that thermocline conditions may have had a dominant influence on long-term evolution of tropical Pacific climate and Walker circulation. There are theories that tropical conditions were altered by the restriction of flow through oceanic gateways in Panama (Haug et al., 2001) and Indonesia (Cane and Molnar, 2001). The impact of these tectonic changes on the thermocline is the subject of active research today. Alternatively, thermocline conditions may be determined by extratropical climate, although not specifically to ice volume (Fedorov et al., 2006). Whatever the cause, it may be that the demise of the permanent El Niño conditions and the strengthening of Walker circulation was an important factor in cooling North America, which allowed ice sheets to grow to their maximum size.

\section{IMPLICATIONS}

Data from Pliocene material collected by the ODP give us a glimpse of conditions during a past warm period. Surprisingly, the "normal" conditions of the modern tropical Pacific, with a well- developed east equatorial cold tongue, a large west-east temperature gradient, and strong Walker circulation are not "normal" from the perspective of the geological past, which was dominated, prior to $\sim 3 \mathrm{Ma}$, by warmer-than-modern climate conditions. The most feasible explanation for how permanent El Niño conditions could persist over long timescales is that the thermocline was deeper or warmer, thereby preventing cool water from upwelling (even if winds were strong). Without cool water upwelling, west-east temperature and pressure gradients would be weak. But, what determines thermocline conditions? One possibility is that reduced horizontal surface-water density gradients due to higher extratropical temperature and/or lower salinity would force the thermocline to be relatively deep (Boccaletti et al., 2004; Fedorov et al., 2006). Once this deepening occurs, teleconnections may cause ample extratropical warming, particularly in North America, keeping Greenland ice sheets relatively small and possibly establishing an El Niño-like pattern of continental climate anomalies around the globe.

More paleoceanographic studies are needed to continue to test the idea that a deeper thermocline and permanent El Niño-like conditions are expected in times of global warmth. This need is particularly urgent in light of anthropogenic forcing of modern climate conditions. Specifically, the relatively high-amplitude swings in climate (Figure 3a) of the last million years or so indicate that our current climate, perhaps more than most intervals in Earth s geological past, is likely to be quite sensitive to perturbations. It may be that the existence of a 
relatively shallow thermocline and the resulting strong air-sea interactions that maintain strong Walker circulation, have caused the Earth to precariously swing between glacial and interglacial states (Ravelo et al., 2004). As such, a perturbation that induces a deeper thermocline, such as that caused by anthropogenically induced global warming, could force the Earth into a warm permanent El Niñolike state.

Over the last $\sim 150$ years, observations of tropical Pacific climate indicate that Walker circulation has been slowing down (Vecchi et al., 2006) (Figure 4).

The mechanisms that are inducing these changes may lie in the atmosphere (Vecchi et al., 2006), but there is also evidence for long-term trends in subsurface conditions in the equatorial Pacific (Cai and Whetton, 2001) and in the Califor- nia margin upwelling region (Palacios et al., 2004), indicating the thermocline might be involved. These studies hint that the ultimate cause of these trends is anthropogenically induced climate change, but many state-of-the-art climate models do not predict that permanent El Niño-like conditions will accompany future global warming (Collins, 2005). As such, there is much work to be done collaboratively between climate theorists and observationalists to put instrumental and paleoceanographic data into context, to devise tests of climate models that will explore whether changes in thermocline conditions and Walker circulation are critical components of past and future climate change, and to build a fundamental understanding of tropical processes and their role in global climate change.

\section{ACKNOWLEDGEMENTS}

None of the ideas presented in this paper would be possible without the material collected by the Ocean Drilling Program and the large group of scientists who worked on the material. This paper is a synthesis of ideas, many of which come from collaborative work with my former and current graduate students Michael Wara and Petra Dekens, and inspired by papers of and discussions with a number of colleagues: Marcelo Barreiro, Katharina Billups, Mark Cane, Alexey Fedorov, Alan Haywood, Gerald Haug, Tim Herbert, Kira Lawrence, Peter Molnar, George Philander, and Maureen Raymo. Many thanks to Mark Leckie and Lowell Stott for their constructive reviews of this paper, and to Gabe Vecchi for providing Figure 4. 四

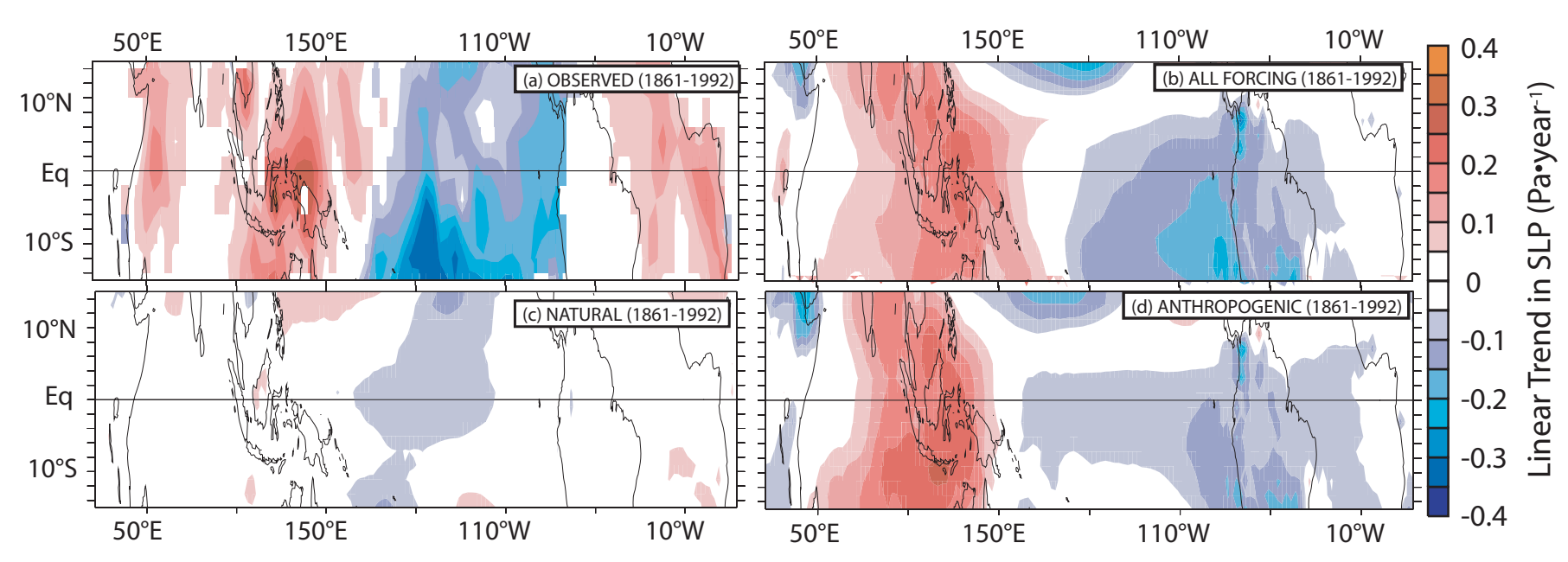

Figure 4. Spatial pattern of observed and modeled sea level pressure (SLP) linear trends from 1861 to 1992 . Trends are shown for (a) measured SLP data (1861 to 1992) (from Kaplan et al., 2000), and the average SLP from an ensemble of General Circulation Model (GCM) experiments as follows: (b) forced with natural (solar input, volcanoes) and anthropogenic (well-mixed greenhouse gases, ozone, direct aerosol forcing, and land use) changes that occurred from 1861 to 1992; (c) forced only with natural changes from 1861 to 1992; (d) forced only with anthropogenic changes from 1861 to 1992. Note that the observations indicate that SLP has increased in the western equatorial Pacific and decreased in the eastern equatorial Pacific, indicative of weakening Walker circulation. Comparison to the GCM results suggests that this weakening has possibly been due to anthropogenic activity. This figure is from Vecchi et al. (2006). 


\section{REFERENCES}

Anand, P., H. Elderfield, and M.H. Conte. 2003. Calibration of $\mathrm{Mg} / \mathrm{Ca}$ thermometry in planktonic foraminifera from a sediment trap time series. Paleoceanography 18:28-21-28-15.

Barreiro, M., G. Philander, R. Pacanowski, and A. Federov. 2005. Simulations of warm tropical conditions with application to middle Pliocene atmospheres. Climate Dynamics 26:349-365, doi 10.1007/s00382-005-0086-4.

Boccaletti, G., R.C. Pacanowski, S.G.H. Philander, and A.V. Federov. 2004. The thermal structure of the upper ocean. Journal of Physical Oceanography 34:888-902.

Broccoli, A.J., K.A. Dahl, and R.J. Stouffer. 2006. Response of the ITCZ to Northern Hemisphere cooling. Geophysical Research Letters 33:L01702, doi:10.1029/2005GL024546.

Cai, W., and P.H. Whetton. 2001. A time-varying greenhouse warming pattern and the tropical-extratropical circulation linkage in the Pacific Ocean. Journal of Climate 14:3,337-3,355.

Cane, M.A. 2005. The evolution of El Niño, past and future. Earth and Planetary Science Letters 230:227-240.

Cane, M.A., and P. Molnar. 2001. Closing of the Indonesian seaway as a precursor to east African aridification around 3-4 million years ago. Nature 411:157-162.

Chaisson, W., and A.C. Ravelo. 2000. Pliocene development of the East-West hydrographic gradient in the Equatorial Pacific. Paleoceanography 15:497-505.

Chiang, J., and C. Bitz. 2005. Influence of high latitude ice cover on the marine Intertropical Convergence Zone. Climate Dynamics 25:477-496, doi 10.1007/ s00382-005-0040-5.

Collins, M., and the CMIP Modeling Groups. 2005. El Niño or La Niña-like climate change? Climate Dynamics 24(1):89-104.

Dekens, P.S., D.S. Lea, D.K. Pak, and H.J. Spero. 2002. Core top calibration of $\mathrm{Mg} / \mathrm{Ca}$ in tropical foraminifera: Refining paleotemperature estimation. Geochemistry, Geophysics, Geosystems, doi:10.1029/ 2001GC000200.

Dekens, P., A.C. Ravelo, and M. McCarthy. In preparation. Warm upwelling regions in the warm Pliocene. Paleoceanography.

Dowsett, H., J. Barron, and R. Poore. 1996. Middle Pliocene sea surface temperatures: A global reconstruction. Marine Micropaleontology 27:13-26.

Fedorov, A., and G. Philander. 2000. Is El Niño changing? Science 288:1,997-2,002.

Fedorov, A.V., R.C. Pacanwski, S.G. Philander, and G. Boccaletti. 2004. The effect of salinity on the winddriven circulation and the thermal structure of the upper ocean. Journal of Physical Oceanography 34:1,949-1,966.

Fedorov, A.V., P.S. Dekens, M. McCarthy, A.C. Ravelo, P.B. deMenocal, M. Barreiro, R.C. Pacanowski, and S.G. Philander. 2006. The Pliocene Paradox (mechanisms for a permanent El Niño). Science 312:1,485-1,489, doi: 10.1126/science.1122666.
Haug, G.H., F. Sigman, D. Tiedemann, R. Pedersen, and T. Sarnthein. 1999. Onset of permanent stratification in the subarctic Pacific Ocean. Nature 401:779-782.

Haug, G.H., R. Tiedemann, R. Zahn, and A.C. Ravelo. 2001. Role of Panama uplift on oceanic freshwater balance. Geology 29:207210.

Haywood, A.M., and P.J. Valdes. 2004. Modelling Pliocene warmth: Contribution of atmosphere, oceans and cryosphere. Earth and Planetary Science Letters 218:363-377.

Haywood, A.M., P. Dekens, A.C. Ravelo, and M. Williams. 2005. Warmer tropics during the mid-Pliocene? Evidence from alkenone paleothermometry and a fully coupled ocean-atmosphere GCM. Geochemistry Geophysics Geosystems 6:Q03010, doi:10.1029/2004GC000799

Herbert, T.D. 2000. Review of alkenone calibrations. Geochemistry, Geophysics, Geosystems 2:2000GC000055.

Herbert, T.D., and J.D. Schuffert. 1998. Alkenone unsaturation estimates of Late Miocene through Late Pliocene sea-surface temperatures at Site 958. Pp. 17-21 in Proceedings of the Ocean Drilling Program, J.V. Firth, ed. Ocean Drilling Program, College Station, TX.

Intergovernmental Panel on Climate Change. 2001. Climate Change: The Scientific Basis. [Online] Available at: http://www.grida.no/climate/ipcc_tar/ wg1/.

Kaplan, A., Y. Kushnir, and M.A. Cane. 2000. Reduced space optimal interpolation of historical marine sea level pressure: 1854-1992. Journal of Climate 13(16):2,987-3,002.

Kurschner, W.M., J. Burgh, H. Visscher, and D.L. Dilcher. 1996. Oak leaves as biosensors of late neogene and early pleistocene paleoatmospheric $\mathrm{CO}_{2}$ concentrations. Marine Micropaleontology 27:299-312.

Lawrence, K.T., Z. Liu, and T.D. Herbert. 2006. Evolution of the eastern tropical Pacific through PlioPleistocene glaciation. Science 312:79-83, doi: 10.1126/science.1120395.

Lisiecki, L.E., and M.E. Raymo. 2005. A PliocenePleistocene stack of 57 globally distributed benthic ${ }^{18} \mathrm{O}$ records. Paleoceanography 20, doi:10.1029/ 2004 PA001071.

Liu, Z., and B. Huang. 2000. Cause of tropical Pacific warming trend. Geophysical Research Letters 27:1,935-1,938.

Liu, Z., and H. Yang. 2003. Extratropical control of tropical climate, the atmospheric bridge and ocean tunnel. Geophysical Research Letters 30:1,230, doi:1210.1029/2002GL016492.

Marlow, J.R., C.B. Lange, G. Wefer, and A. RosellMelé. 2000. Upwelling intensification as part of the Pliocene-Pleistocene climate transition. Science 290:2,288-2,291.

Molnar, P., and M.A. Cane. 2002. El Niño's tropical climate and teleconnections as a blueprint for pre-Ice Age climates. Paleoceanography 17, doi: 10.1029/2001PA000663.

Mudelsee, M., and M.E. Raymo. 2005. Slow dynamics of the Northern Hemisphere glaciation. Paleoceanography 20:PA4022, doi:10.1029/2005PA001153.

Palacios, D., S.J. Bograd, R. Mendelssohn, and E.B. Schwing. 2004. Long-term and seasonal trends in stratification in the California Current, 1950-1993. Journal of Geophysical Research 109:1-12.

Nurnberg, D., J. Bijma, and C. Hemleban. 1996. Assessing the reliability of magnesium in foraminiferal calcite as a proxy for water mass temperatures. Geochimica et Cosmochimica Acta 60:803.

Philander, S.G., and A. Fedorov. 2003a. Is El Niño sporadic or cyclic? Annual Review of Earth and Planetary Sciences 31:579-594.

Philander, S.G., and A.V. Fedorov. 2003b. Role of tropics in changing the response to Milankovich forcing some three million years ago. Paleoceanography 18(2):1,045, doi:10.1029/2002PA000837.

Ravelo, A.C., and C. Hillaire-Marcel. In press. The use of oxygen and carbon isotopes of foraminifera in studies of paleoceanography. In: Proxies in Late Cenozoic Paleoceanography, C. Hillaire-Marcel, and A. de Vernal. Elsevier, Amsterdam, The Netherlands.

Ravelo, A.C., D.H. Andreasen, M. Lyle, L.A. Olivarez, and M.W. Wara. 2004. Regional climate shifts caused by gradual global cooling in the Pliocene epoch. Nature 429:263-267.

Ravelo, A.C., P.S. Dekens, and M. McCarthy. 2006. Evidence for El Niño-like conditions during the Pliocene. GSA Today 16:4-11.

Raymo, M.E., and K. Nisancioglu. 2003. The 41 kyr world: Milankovitch's other unsolved mystery. Paleoceanography 18(1):1011, doi:10.1029/ 2002 PA000791.

Raymo, M.E., W.F. Ruddiman, J. Backman, B.M. Clement, and D.G. Martinson. 1989. Late Pliocene variation in northern hemisphere ice sheets and North Atlantic deepwater circulation. Paleoceanography 4:413-446.

Raymo, M.E., B. Grant, M. Horowitz, and G.H. Rau. 1996. Mid-Pliocene warmth: Stronger greenhouse and stronger conveyor. Marine Micropaleontology 27:313-326.

Rohling, E.J., and S. Cooke. 1999. Stable oxygen and carbon isotope ratios in foraminiferal carbonate. Pp. 239-258 in Modern Foraminifera, B.K. Sen Gupta, ed. Kluwer Academic, Dordrecht, The Netherlands.

Sloan, L.C., T.J. Crowley, and D. Pollard. 1996. Modeling of middle Pliocene climate with the NCAR GENESIS general circulation model. Marine Micropaleontology 27:51-61.

Van der Burgh, J., H. Visscher, D.L. Dilcher, and W.M. Kurschner. 1993. Paleoatmospheric signatures in Neogene fossil leaves. Science 260:1,778-1,790.

Vecchi, G.A., B.J. Soden, A.T. Wittenberg, I.M. Held, A. Leetmaa, and M.J. Harrison. 2006. Weakening of tropical Pacific atmospheric circulation due to anthropogenic forcing. Nature 441:73-76.

Wara, M.W., A.C. Ravelo, and M.L. Delaney. 2005. Permanent El Niño -like conditions during the Pliocene Warm Period. Science 309:758-761. 